\title{
The role of exercise echocardiography in the diagnosis of heart failure with preserved left ventricular ejection fraction (primary diastolic heart failure)
}

\author{
Jaroslav Meluzin \\ ${ }_{15 t}^{\text {Dt }}$ epartment of Internal Medicine/Cardioangiology, St. Anne's University Hospital, Masaryk University, Brno, Czech Republic
}

Meluzin J. The role of exercise echocardiography in the diagnosis of heart failure with preserved left ventricular ejection fraction (primary diastolic heart failure). Cor Vasa 2010;52:162-167.

The purpose of this review article is to provide data on the role of exercise echocardiography in the diagnosis of heart failure with preserved left ventricular ejection fraction (primary diastolic heart failure). Diastolic heart failure (DHF) accounts for $30 \%-50 \%$ of all cases of heart failure and has a poor prognosis. The main abnormality in DHF is an increase in left ventricular filling pressure (LVFP) as a consequence of increased LV stiffness. Current guidelines defining DHF based only on resting hemodynamic values do not allow diagnosing DHF in patients whose signs (dyspnea most often) and pathological values are confined to exercise only. Recently, one quarter to one third of DHF patients have been found to show elevated LVFP only during exercise. Diastolic exercise echocardiography enables us to reveal this latent, only exercise-induced DHF by measuring the ratio of early diastolic transmitral flow velocity to early diastolic mitral annular velocity (E/Ea). An exercise-induced increase in E/Ea $>13$ predicts an elevated LVFP with a sensitivity of $73 \%$ and a specificity of $96 \%$. However, as not all studies have confirmed the accuracy of E/Ea in predicting the exercise-induced increase in LVFP and the numbers of patients studied are small, caution needs to be exercised when interpreting the results of exercise tests. Further studies are warranted to confirm the current parameters or to identify new ones to allow accurately establishing the diagnosis of exercise-induced DHF.

Key words: Exercise echocardiography - Diastolic heart failure

Meluzin J. Úloha zátěžové echokardiografie v diagnostice diastolického srdečního selhání s normální ejekční frakcí levé komory (primární diastolické srdeční selhání). Cor Vasa 2010;52:162-167.

Cílem tohoto souhrnného článku bylo podat informace o úloze zátěžové echokardiografie v diagnostice srdečního selhání s normální ejekční frakcí levé komory (primární diastolické srdeční selhání). Diastolické srdeční selhání (DHF) je příčinou srdeční slabosti ve 30-50 \% a je spojeno se špatnou prognózou. Hlavní abnormalitou u DHF je vzestup plnicího tlaku levé komory (LVFP), který vzniká jako důsledek vzestupu tuhosti levé komory. Současná pravidla definující DHF jsou tvořena na základě měření klidových hodnot a neumožňují diagnostikovat DHF u nemocných, u nichž jsou symptomy (nejčastěji dušnost) a patologické hodnoty diastolické funkce levé komory omezeny pouze na dobu zátěže. Udává se, že asi jedna čtvrtina až jedna třetina nemocných má známky vzestupu LVFP pouze během zátěže. Diastolická zátěžová echokardiografie umožňuje odhalit tuto latentní formu DHF měřením poměru vrcholové rychlosti časného diastolického plnění levé komory a vrcholové rychlosti pohybu mitrálního anulu v časné diastole (poměr E/Ea). Zátěží navozený vzestup E/Ea > 13 umožňuje předpovědět vzestup LVFP nad normu se senzitivitou $73 \%$ a specificitou $96 \%$. Nicméně ne všechny studie prokázaly přesnost poměru E/Ea pro předpověd' zátěží navozeného vzestupu LVFP a počty nemocných v těchto studiích byly nízké, což vyžaduje opatrnost při hodnocení zátěžových testů. Proto je třeba dalších studií, které by měly zhodnotit užitečnost současně užívaných parametrů a popřípadě určit parametry nové, jež umožní přesnou diagnostiku DHF navozeného zátěží.

Klíčová slova: Zátěžová echokardiografie - Diastolické srdeční selhání

Address: prof. Jaroslav Meluzin, M.D., PhD., FESC, $1^{\text {st }}$ Department of Internal Medicine/Cardioangiology, St. Anne's University Hospital, Pekařská 53, 65691 Brno, Czech Republic, e-mail: jaroslav.meluzin@fnusa.cz 


\section{Introduction}

Exertional dyspnea is a very common symptom encountered in everyday clinical practice of cardiology. Following exclusion of non-cardiac causes of exertional dyspnea, cardiologists frequently face a situation whereby resting non-invasive cardiac examinations including echocardiography, magnetic resonance imaging, single-photon emission computed tomography, etc., demonstrate normal heart morphology and function. In such a situation, exercise can give an answer as to the reason for symptoms and how to manage them. The most likely explanation for exertional dyspnea is exercise-induced systolic, diastolic, or combined myocardial dysfunction frequently leading to heart failure symptomatology. While exercise-induced systolic dysfunction due to myocardial ischemia is commonly diagnosed by many non-invasive methods and parameters, the non-invasive approach to diagnose exercise-induced diastolic heart failure is not very well clinically validated and utilized. At present, echocardiography represents the most widely utilized tool for the assessment of diastolic function and for the non-invasive diagnosis of primary diastolic heart failure (DHF). Exercise echocardiography focusing on the evaluation of diastolic function may be the initial step for the diagnosis of DHF manifesting only during exercise. The purpose of this review article is to provide and discuss current data on the role of diastolic exercise echocardiography in the differential diagnosis of exertional dyspnea and in the diagnosis of exercise-induced DHF.

\section{Clinical importance of diastolic heart failure}

Diastolic dysfunction has been shown to be an important and frequent cause of heart failure. It may be associated with systolic dysfunction or be the cause of heart failure with preserved left ventricular ejection fraction (HFPEF), i.e., with primary DHF. At present, DHF accounts for approximately $30 \%-50 \%$ of cases of heart failure. ${ }^{1-3}$ Patients with DHF are more likely to be older and female and to have a history of hypertension, diabetes mellitus, and atrial fibrillation. ${ }^{3,4}$ The prognosis of patients with DHF appears to be only marginally better than ${ }^{2}$ or comparable ${ }^{3}$ to that of patients with heart failure due to reduced left ventricular ejection fraction (LVEF). Bhatia et al. ${ }^{3}$ reported, in 2,802 patients with the diagnosis of DHF at discharge, mortality rates of $5 \%$ at 30 days after discharge and $22 \%$ at one year post-discharge. However, survival was found to improve over time in heart failure patients with reduced LVEF, but not in those with preserved LVEF. ${ }^{2}$ Thus, it is obvious that DHF represents an important medical problem deserving close attention.

\section{Symptomatology of patients with diastolic heart failure}

The main clinical symptoms of patients with DHF are fatigue and dyspnea on exertion. To identify the underlying mechanisms, Kitzman et al. ${ }^{5}$ performed invasive cardiopulmonary exercise testing in seven patients with DHF (HFPEF) and in 10 age-matched normal subjects. The patients with DHF demonstrated severe exercise intolerance with a $48 \%$ reduction in peak oxygen consumption. At rest, there was no difference in cardiac index, stroke volume index or heart rate between the two groups. Compared with normal subjects, cardiac index was significantly reduced at comparable submaximal workloads and was markedly reduced, by $41 \%$, at peak exercise, in proportion to reduction in peak $\mathrm{VO}_{2}$. Stroke volume index was reduced in patients compared to controls during submaximal exercise and was markedly reduced by $26 \%$ at peak exercise. Similarly, heart rate was slightly reduced during submaximal exercise, but was reduced by $18 \%$ at peak exercise. Rest and exercise LVEF and end-systolic volume index were comparable in patients and normal subjects. In contrast, end-diastolic volume index was reduced during submaximal exercise and at peak exercise in patients. Pulmonary capillary wedge pressure (PCWP) increased slightly from rest to peak exercise in normal subjects (from $3 \pm 3$ to $7.1 \pm 4.4 \mathrm{mmHg}$ ), but rose markedly in patients (from $10 \pm 6$ to $25.7 \pm 9.1$ $\mathrm{mmHg}$ ). Skaluba et al. ${ }^{6}$ evaluated the association of various echocardiographic parameters with exercise tolerance in 121 subjects with a mean LVEF of $60 \%$. Among all of the echocardiographic parameters measured, the best individual correlate of exercise performance was the E/Ea ratio (ratio of peak early diastolic transmitral flow velocity to peak early diastolic mitral annular velocity) reflecting LV filling pressure (LVFP). There was a similar exercise capacity in patients with a normal mitral inflow pattern and those with a slow relaxation pattern $(\mathrm{E} / \mathrm{A}<1.0)$ when $\mathrm{E} / \mathrm{Ea}$ was $<10$. In contrast, subjects with slowed relaxation and $\mathrm{E} / \mathrm{Ea} \geq 10$ had a markedly reduced exercise performance as did patients with a pseudonormal/restrictive LV filling pattern. An $\mathrm{E} / \mathrm{Ea} \geq 10$ was found to be a significant independent predictor of reduced exercise tolerance. In summary, in patients at peak exercise, a reduced stroke volume index is the primary factor responsible for the reduced cardiac index, which is in turn the primary factor in the reduction of peak $\mathrm{VO}_{2}$. The main determinant of an abnormal stroke volume response to exercise is a reduction of end-diastolic volume index during exercise despite a marked elevation of LVFP and a reduced heart rate. However, isolated relaxation abnormalities (grade I diastolic dysfunction) are unlikely to cause any significant exercise intolerance and an increase in LVFP is a prerequisite for a marked reduction in exercise performance. These data suggest that, in DHF patients, exercise tolerance is reduced primarily because of abnormalities of diastolic function that limit LV filling and, consequently, increase LVFP and reduce the stroke volume response to exercise.

Recently, several authors have suggested that the pathophysiology of DHF (HFPEF) is a complex process involving not only relaxation disturbances and an increase in myocardial stiffness but, also, systolic contractile abnormalities with a decrease in cardiac energy status. ${ }^{7-9}$ They reported a decrease in longitudinal and radial myocardial strains, in systolic mitral annular velocities, and in apical rotation, even in patients with preserved LVEF. ${ }^{9}$ These systolic abnormalities are present at rest, but mainly during exercise, and may contribute to a worsening of LV 
diastolic filling through delayed and reduced LV untwisting and reduced LV suction. Thus, because LV systolic and diastolic functions are closely coupled, ${ }^{10}$ it is likely that DHF is a syndrome resulting from both diastolic and systolic dysfunction. However, the role of systolic dysfunction and its contribution to a patient's symptomatology has not yet been defined and is still under intensive research.

\section{Diagnosis of diastolic heart failure and the role of echocardiography}

The criteria for the diagnosis of DHF (= HFPEF) have been formulated by consensus of experts of the Heart Failure and Echocardiography Associations of the European Society of Cardiology (ESC). ${ }^{11}$ The diagnosis of DHF requires the following criteria to be met: 1 , signs or symptoms of heart failure, 2, normal or mildly abnormal systolic LV function defined by LVEF $>50 \%$ and LV end-diastolic volume index $<97 \mathrm{~mL} / \mathrm{m}^{2}$ and 3, presence of diastolic LV dysfunction. Evidence of diastolic LV dysfunction can be obtained invasively or non-invasively using conventional and tissue Doppler echocardiography. The basic non-invasive parameter to diagnose DHF is the ratio of early diastolic transmitral filling flow (E) to early diastolic annular velocity (Ea). An E/Ea > 15 is indicative of DHF without any need for other investigations. Borderline values of $\mathrm{E} / \mathrm{Ea}$ $(15>\mathrm{E} / \mathrm{Ea}>8)$ require additional investigations to be performed to diagnose DHF. They include blood flow Doppler ultrasound of the mitral valve and pulmonary veins, echocardiographic measurements of LV mass index or left atrial volume index, electrocardiography to reveal atrial fibrillation, and determination of the plasma levels of natriuretic peptides. An increase in plasma natriuretic peptide levels alone is not enough for the diagnosis of DHF to be established and requires additional echocardiographic evidence of LV diastolic dysfunction or the presence of atrial fibrillation. The ESC guidelines thus clearly document the pivotal role of echocardiography and an increase in E/Ea in the diagnosis of DHF. The important role of E/Ea results from its ability to predict non-invasively an increase in LVFP as has been repeatedly confirmed by many authors. ${ }^{12-15}$ In the most important paper, Ommen et al. ${ }^{16}$ were the first to publish a cut-off value of $\mathrm{E} / \mathrm{Ea}>15$ as a predictor of an increase in LVFP with a specificity of $86 \%$ (64\% positive predictive value), while a $97 \%$ negative predictive value was reported for an $\mathrm{E} / \mathrm{Ea}<8$. However, it should be emphasized that the E/Ea cut-off value of 15 is applicable only to Ea measurements using spectral tissue Doppler. For color-tissue Doppler to be used, another cut-off E/Ea value for the diagnosis of DHF has to be defined as color-tissue Doppler underestimates myocardial velocities while overestimating $\mathrm{E} / \mathrm{Ea} .{ }^{17}$ An increase in LVFP is the consequence of increased LV stiffness shown to be the main abnormality in DHF. ${ }^{18}$ Thus, an increase in E/Ea is suggestive of DHF with an increase in myocardial stiffness and LVFP. However, in many patients, LVFP at rest is normal and rises only under conditions of cardiovascular stress including exercise. In those patients, LVFP estimation at rest provides only incomplete information and stress-induced changes in
LVFP must be analyzed in order to diagnose stress-induced DHF.

\section{The importance of exercise for the diagnosis of stress-induced diastolic heart failure}

As exertional dyspnea is a characteristic sign of DHF, it seems reasonable to assess LVFP not only at rest but, also, during exercise. Exercise is important mainly in situations whereby patients have diseases commonly associated with diastolic dysfunction (hypertension, diabetes mellitus, various diseases accompanied by LV hypertrophy, etc.), the resting LV systolic and diastolic function is normal, and non-cardiac causes of dyspnea have been ruled out. However, even the presence of minor disturbances of resting $\mathrm{LV}$ diastolic function (mostly mild relaxation abnormalities) in those patients does not necessarily indicate that the dyspnea is a consequence of diastolic dysfunction. A documented increase in LVFP with exercise shows more convincingly that the dyspnea is due to a problem with LV filling. In an invasive study of Burgess et al., ${ }^{19}$ approximately one quarter of the patients manifested an elevated LV diastolic pressure only during exercise. In a non-invasive part of the same study, ${ }^{19}$ the authors demonstrated that an abnormal exercise E/Ea occurred in over a third of patients with normal filling and delayed relaxation at rest. Thus, if omitting exercise testing, DHF can be left undiagnosed in a significant proportion of patients with exertional dyspnea.

\section{Behavior of left ventricular filling pressure and the E/Ea ratio in healthy subjects}

Before studying the exercise-induced changes in the E/Ea ratio and LVFP in diseased hearts, it is important to know their physiological changes under various conditions in healthy subjects. First, we have to consider the potential effect of aging on diastolic functional parameters. Tighe et al. ${ }^{20}$ analyzed E, A (peak late transmitral flow velocity), E/A, $\mathrm{Ea}$ (taken from the lateral mitral annulus), Aa (peak late diastolic annular velocity), E/Ea, and other parameters in 103 healthy men and women aged 23 to 88 years. The study group was divided into deciles by age (20-29, 30-39, 40-49, up to 80 years or more) for the purpose of analyzing age-related parameter changes. The mean values of E/Ea, were as follows (mean \pm SD): $4.0 \pm 1.0,5.0 \pm 1.0,5.2 \pm 1.2$, $5.7 \pm 1.4,6.2 \pm 1.8,7.2 \pm 3.2$, and $8.0 \pm 2.4$, respectively $(p<0.0001)$. While $\mathrm{E}$ did not vary significantly with age, there was a very significant decrease in Ea velocities with advancing age. As a consequence, the E/Ea ratios increased progressively with age. Several healthy subjects over 70 years of age had an E/Ea ratio $>8$, i.e., a value suggested to indicate a possible LVFP elevation. ${ }^{16}$ The significant positive correlations of E/Ea with age were confirmed in a large study of 1,012 subjects without cardiovascular disease. ${ }^{21}$ The mean values of $\mathrm{E} / \mathrm{Ea}$ from the septal and the lateral annulus were $9.32 \pm 3.32$ and $8.32 \pm 2.81$, respectively, in patients $\geq 70$ years. Similar results were obtained by De Sutter et al. ${ }^{22}$ reporting mean values of $\mathrm{E} / \mathrm{Ea}>8$ already in normal subjects over 45 years of age. Concerning the effect of age 
on LVFP, Remmen et al. ${ }^{23}$ measured invasively PCWP in a group of 28 elderly healthy subjects (mean age $70 \pm 4$ years) at rest. In the supine position, mean PCWP was $9.8 \pm 1.9 \mathrm{mmHg}$ (range from 6.7 to $14.0 \mathrm{mmHg}$ ) while, in the semirecumbent position, mean PCWP was $8.9 \pm 2.1 \mathrm{mmHg}$ (range, $4.6-12.5 \mathrm{mmHg}$ ). In another study ${ }^{24}$ evaluating younger healthy volunteers (mean age, $37.2 \pm 8.9$ years), PCWP values ranged from 8.0 to $13.3 \mathrm{mmHg}$ (mean, $10.3 \pm 2.0 \mathrm{mmHg}$ ). These results are consistent with findings of Prasad et al. ${ }^{25}$ who failed to observe a significant effect of aging on PCWP. The divergent effects of aging on E/Ea ratio and PCWP could be explained by the absence of a correlation between PCWP and E/Ea in healthy subjects. ${ }^{24}$ In summary, LVFP represented by PCWP is not affected significantly by aging. In contrast, the $\mathrm{E} /$ Ea ratio increases with aging and may exceed the cut-off value of 8 in mainly elderly healthy subjects over 70 years. For healthy subjects, the upper normal limit for PCWP should probably be the value of $15 \mathrm{mmHg}$ rather than $12 \mathrm{mmHg}$, the latter being recommended by the ESC guidelines for the diagnosis of DHF ${ }^{11}$

Several authors studied the effects of exercise on echocardiographic parameters related to diastolic function and on invasively measured PCWP (a common clinical surrogate for LVFP) in normal subjects. Ha et al. ${ }^{26}$ assessed exercise-induced mitral inflow and annular velocity changes in 31 healthy subjects. Immediately after exercise, E, A, Ea, and Aa significantly increased with no change in E/A (from 1.1 at rest to 1.1 post-exercise) and the $\mathrm{E} / \mathrm{Ea}$ ratio (from 6.7 to 6.6). The deceleration time (DT) of E wave decreased significantly. The same authors ${ }^{27}$ studied, in a larger cohort of 73 healthy subjects, the E/Ea ratio at rest, during exercise at workloads of $25 \mathrm{~W}$ and $50 \mathrm{~W}$, and during recovery at 2 , 5 , and $10 \mathrm{~min}$ after completing exercise. The resting value of $7.6 \pm 1.8$ increased slightly to $8.6 \pm 2.2$ and to $8.8 \pm 1.9$ during exercise reaching $8.8 \pm 1.9,8.2 \pm 2.0$, and $7.8 \pm 1.8$ during recovery, respectively. None of the subjects had an $\mathrm{E} / \mathrm{Ea}>15$ during either exercise or recovery. The authors demonstrated that LVFP assessment upon completing treadmill exercise is acceptable. Concerning invasive measurement of LVFP, Okada et al. ${ }^{28}$ reported a decrease or no change in invasively measured PCWP with exercise in the supine position (mean PCWP of $7.2 \pm 3.0 \mathrm{mmHg}$ decreased to $3.7 \pm 2.2 \mathrm{mmHg}$ ). Higginbotham et al. ${ }^{29}$ measured PCWP in 24 asymptomatic males aged 20-50 years. Pulmonary capillary wedge pressure decreased from $9 \pm 3 \mathrm{mmHg}$ at rest to $3 \pm 2 \mathrm{mmHg}$ with a change from the supine to upright position further increasing to $10 \pm 3 \mathrm{mmHg}$ at peak upright exercise. Thadani et al. ${ }^{30}$ observed, in 10 patients without demonstrable cardiovascular disease, an increase in PCWP from $6 \pm 1 \mathrm{mmHg}$ to $13 \pm 1 \mathrm{mmHg}$ during supine exercise, and from $4 \pm 1 \mathrm{mmHg}$ to $8 \pm 1 \mathrm{mmHg}$ during sitting exercise. Similarly, Kitzman et al. ${ }^{5}$ found an increase in PCWP during upright exercise from $3 \pm 3$ to $7.1 \pm 4.4 \mathrm{mmHg}$ in 10 healthy subjects.

In summary, the physiological response to exercise is an increase in E, A, Ea, and $\mathrm{Aa}$ and a shortening of DT of E wave and isovolumic relaxation time (IRT). There are no significant exercise-induced changes in the E/A or E/Ea ratio. These changes result from an increase in LV relaxation, mainly due to a positive relaxation-frequency relationship, an increased sympathetic tone, and increased elastic recoil. No change in E/Ea implies the absence of an exercise-induced increase in LVFP. Pulmonary capillary wedge pressure in healthy subjects depends on the body position being lower in subjects in the upright position. The exercise-induced changes in PCWP vary considerably, but a peak upright exercise PCWP $>13 \mathrm{mmHg}$ is very unlikely.

\section{The effect of exercise on echocardiographic functional parameters in patients with cardiovascular disease}

Rustad et al. ${ }^{31}$ studied conventional and Doppler tissue imaging-derived diastolic functional parameters at rest and during upright exercise in 18 patients with their first myocardial infarction (MI) and 18 age-matched healthy volunteers. Ea increased significantly in healthy controls (from 6.8 to $8.7 \mathrm{~cm} / \mathrm{s}$ ), but did not change in the MI group (from 6.4 to $6.5 \mathrm{~cm} / \mathrm{s}$ ). E declined significantly in both groups during exercise as did A, while the DT of the early filling wave and IRT were significantly shortened. The E/Ea ratio indicating an increase in LVFP rose only in the MI group. Similar changes in E and DT during exercise were reported by Podolec et al. ${ }^{32}$ in 50 patients with severe systolic LV dysfunction, mostly of ischemic etiology. In patients with low exercise tolerance, A did not change with exercise, resulting in an increase in the $\mathrm{E} / \mathrm{A}$ ratio, while Ea slightly increased (from $4.3 \pm 1.4$ to $4.8 \pm 1.4 \mathrm{~cm} / \mathrm{s}$ ) resulting in a mild increase in $\mathrm{E} / \mathrm{Ea}$, from $19.2 \pm 7.7$ to $20.9 \pm 5.5$. In patients with higher exercise tolerance, Ea increased from $5.5 \pm 2.3$ to $6.2 \pm 2.1 \mathrm{~cm} / \mathrm{s}$, leading to an increase in $\mathrm{E} / \mathrm{Ea}$ from $13.2 \pm 5$ to $15.9 \pm 4.7$. In this study, $\mathrm{E} / \mathrm{Ea}$ at peak stress correlated with exercise capacity $(\mathrm{r}=-0.75)$ and was the most useful parameter for identifying severe exercise intolerance, as indicated by a peak oxygen uptake of less than $14 \mathrm{~mL} / \mathrm{kg} / \mathrm{min}$. Ha et al. ${ }^{33}$ studied 45 patients with exertional dyspnea and normal LVEF using diastolic stress echocardiography. Twenty-six patients had an E/Ea $\leq 10$ (Group 1) and 19 had an E/Ea $>10$ (Group 2). As for Group 1, 17 patients did not show any increase in E/Ea during exercise (from $8.7 \pm 1.9$ to $6.4 \pm 2.6$ ) whereas nine did (from $9.2 \pm 0.8$ to $13.5 \pm 3.4$ ). In Group 2, E/Ea did not increase during exercise (from $16.0 \pm 4.1$ to $13.5 \pm 4.5$ ). Patients with an $\mathrm{E} / \mathrm{Ea}<10$ at both rest and exercise had significantly longer exercise duration than those in the remaining groups. The close relationship of E/Ea to exercise capacity was confirmed by Donal et al. ${ }^{34}$ In another study, Ha et al. ${ }^{4}$ analyzed echocardiographic data at rest and during supine bicycle ergometry in 141 patients with normal LVEF and abnormal LV relaxation. In contrast to the parameters of diastolic function measured at rest, the exercise-induced changes in diastolic function were related to exercise tolerance. Low exercise tolerance was associated with an exercise-induced decrease in the diastolic functional reserve index and an increase in E/Ea. In a similar cohort of patients with impaired relaxation and normal LVEF, Fukuda et al. ${ }^{35}$ demonstrated that E/Ea after exercise, but not at rest, 
significantly correlated with brain natriuretic peptide (BNP) levels. Recently, Tan et al. ${ }^{9}$ described, in 56 patients with HFPEF, both systolic and diastolic functional abnormalities presenting mainly during exercise, which were found to be significantly related to exercise intolerance. These abnormalities included peak systolic and early diastolic mitral annular velocity, apical rotation, untwist in early diastole, E/Ea, and mitral flow propagation velocity.

In conclusion, exercise echocardiography is clinically feasible and can reveal early diastolic dysfunction and increased LVFP. The exercise-induced increase in the E/Ea ratio is associated with low exercise tolerance and increased BNP levels. The clinical relevance of exercise-induced abnormalities in LV longitudinal systolic function, apical rotation, and diastolic untwisting has yet to be elucidated.

\section{The non-invasive prediction of left ventricular filling pressure during exercise}

At present, there is only little information about non-invasive diagnosis of the exercise-induced increase in LVFP. Here, we rely mainly on the exercise-induced increase in the $\mathrm{E} / \mathrm{Ea}$ ratio. However, the importance of $\mathrm{E} / \mathrm{Ea}$ for the diagnosis of increased LVFP was validated mainly under resting conditions, and data on the relationship of exercise-induced changes in E/Ea and LVFP (or their surrogates such as PCWP or LV end-diastolic pressure, LVEDP) are scarce. Burgess et al. ${ }^{19}$ investigated 37 patients with suspected or known coronary artery disease simultaneously by echocardiography and left-heart catheterization at rest and during single-leg supine bicycle ergometry. Twenty patients had normal LV diastolic pressure (LVDP $\leq 15 \mathrm{mmHg}$ ) both at rest and during exercise while eight had increased LVDP both at rest and during exercise. Nine patients (24\%) had normal resting LVDP, which became elevated during exercise. Patients with normal LVDP both at rest and during exercise showed no significant changes in E/Ea with exercise (from $9.8 \pm 2.4$ to $10.3 \pm 2.1$ ) the same as those with an elevated mean LVDP at rest (from $16.3 \pm 4.9$ to $18.1 \pm 8.6$ ). In patients with mean LVDP elevated only during exercise, E/Ea rose significantly from $11.8 \pm 4.7$ to $16.1 \pm 6.7$ with exercise. There was a good correlation between $\mathrm{E} / \mathrm{Ea}$ and LVDP both at rest $(r=0.67)$ and during exercise $(r=0.59)$. An exercise E/Ea $>13$ predicted an elevated exercise mean LVDP with a sensitivity of $73 \%$ and a specificity of $96 \%$. The exercise E/Ea ratio correlated weakly but significantly with exercise capacity $(r=-0.44)$. However, in the non-invasive part of this study including 166 patients, exercise-induced changes in $\mathrm{E} / \mathrm{Ea}$ were minimal in patients with both exercise $\mathrm{E} / \mathrm{Ea} \leq 13$ (from $9.9 \pm 2.4$ to $9.2 \pm 2.1$ ) and exercise $\mathrm{E} / \mathrm{Ea}>13$ (from $15.1 \pm 5.2$ to $16.9 \pm 4.8$ ). Talreja et al. ${ }^{36}$ validated the E/Ea ratio as a measure of LVFP in 12 patients with exertional dyspnea and normal LV EF. Transmitral E increased from $0.88 \pm 0.2 \mathrm{~m} / \mathrm{s}$ to $1.29 \pm 0.4 \mathrm{~m} / \mathrm{s}$, whereas mitral annular Ea increased from $0.08 \pm 0.02 \mathrm{~m} / \mathrm{s}$ to $0.11 \pm 0.06 \mathrm{~m} / \mathrm{s}$ during exercise. The $\mathrm{E} / \mathrm{Ea}$ ratio rose from $11.7 \pm 0.5$ to $14.4 \pm 0.6$, and PCWP from $14 \pm 4$ to $23 \pm 10 \mathrm{mmHg}$ at peak exercise. The sensitivity of an $\mathrm{E} / \mathrm{Ea} \leq 15$ as a predictor for a normal PCWP during exercise was $89 \%$. Conversely, all the patients with an E/Ea $>15$ showed elevated PCWP during exercise. Both Burgess et al..$^{19}$ and Talreja et al. ${ }^{36}$ concluded that $\mathrm{E} /$ Ea provides a reliable estimation of PCPW not only at rest, but also during exercise. However, two important limitations should be borne in mind: the heterogeneous patient population in the study by Burgess including patients with significant coronary artery disease and LV systolic dysfunction, and the very small number of patients analyzed in Talreja's study. The clinical applicability of E/Ea changes during exercise for the diagnosis of exercise-induced DHF in patients with various cardiac diseases was contested by the study of Dalsgaard et al. ${ }^{37}$ They studied 28 patients with aortic stenosis using multistage supine bicycle exercise and simultaneous right-heart catheterization. Pulmonary capillary wedge pressure increased markedly from $18 \pm 8 \mathrm{mmHg}$ at rest to $39 \pm 10 \mathrm{mmHg}$ at peak exercise, whereas $\mathrm{E} / \mathrm{Ea}$ septal remained unchanged $(19 \pm 6)$ and E/Ea lateral increased minimally (from $14 \pm 4$ to $15 \pm 4$ ). The absence of exercise-induced changes in E/Ea was caused by a proportional increase in E and Ea. This was unexpected for Ea, which increased significantly both at the septal (from $4.7 \pm 0.8 \mathrm{~cm} / \mathrm{s}$ to $7.3 \pm 1.6 \mathrm{~cm} / \mathrm{s}$ ) and lateral (from $6.4 \pm 1.3 \mathrm{~cm} / \mathrm{s}$ to $9.0 \pm 2.1 \mathrm{~cm} / \mathrm{s}$ ) mitral annular corners. Thus, even if both E/Ea septal and E/Ea lateral correlated significantly with PCWP both at rest and during peak exercise, the changes in $\mathrm{E} / \mathrm{Ea}$ septal and $\mathrm{E} / \mathrm{Ea}$ lateral were not related to the changes in PCWP during exercise. The authors concluded that $\mathrm{E} / \mathrm{Ea}$ cannot be used to detect exercise-induced changes in PCWP in patients with aortic stenosis.

What are the reasons for the above discrepancies in the behavior of Ea during exercise, which account for the differences in E/Ea changes during exercise? First, it is likely that $\mathrm{Ea}$ is not preload-independent ${ }^{38,39}$ and may partly pseudonormalize with high LV filling pressures. Another important point may be the etiology of DHF. In patients with coronary artery disease and stress-induced ischemia, no significant changes in Ea and an increase in E/Ea during stress have been reported, ${ }^{40}$ probably as a consequence of ischemia leading to worsening of myocardial relaxation. In contrast, a significant increase in Ea but no change in E/Ea during exercise was found in patients with aortic stenosis. ${ }^{37}$ The exercise-induced increase in Ea may reflect a different effect of LV hypertrophy and, probably, structural abnormalities on Ea behavior during exercise under sympathetic stimulation. Thus, further studies are necessary to study the attributes of Ea behavior during exercise and to determine the role of $\mathrm{E} / \mathrm{Ea}$ changes in predicting increased LVFP during exercise.

\section{Conclusion}

Diastolic heart failure accounts for $30-50 \%$ of all cases of heart failure and has a poor prognosis. The main abnormality in DHF is an increase in LVFP as a consequence of increased LV stiffness. Current guidelines defining DHF based only on resting hemodynamic values do not allow diagnosing DHF in patients whose signs (dyspnea) and pathological 
values are confined to exercise only. Recently, one quarter to one third of patients have been found to show elevated LVFP only during exercise. Diastolic exercise echocardiography enables us to reveal this latent, only exercise-induced DHF by measuring the E/Ea ratio. An exercise-induced increase in $\mathrm{E} / \mathrm{Ea}>13$ predicts an elevated LVFP with a sensitivity of $73 \%$ and a specificity of $96 \%$. However, as not all studies have confirmed the ability of E/Ea to predict the exercise-induced increase in LVFP and the numbers of patients studied are small, caution needs to be exercised when interpreting the results of exercise tests. Further studies are warranted to confirm the current parameters or to identify new ones to allow accurately establishing the diagnosis of exercise-induced DHF.

\section{References}

1. Redfield MM, Jacobsen SJ, Burnett JC, et al. Burden of systolic and diastolic ventricular dysfunction in the community. JAMA 2003;289: 194-202.

2. Owan TE, Hodge DO, Herges RM, et al. Trends in prevalence and outcome of heart failure with preserved ejection fraction. N Engl J Med 2006;355: 251-259.

3. Bhatia RS, Tu JV, Lee DS, et al. Outcome of heart failure with preserved ejection fraction in a population-based study. N Engl J Med 2006;355: 260-269

4. Ha JW, Choi D, Park S, et al. Left ventricular diastolic functional reserve during exercise in patients with impaired myocardial relaxation at rest. Heart 2009;95:399-404.

5. Kitzman DW, Higginbotham MB, Cobb FR, et al. Exercise intolerance in patients with heart failure and preserved left ventricular systolic function: failure of the Frank-Starling mechanism. J Am Coll Cardiol 1991;17: 1065-1072.

6. Skaluba SJ, Litwin SE. Mechanisms of exercise intolerance. Insights from tissue Doppler imaging. Circulation 2004;109:972-977.

7. Phan TT, Abozguia K, Shivu GN, et al. Heart failure with preserved ejection fraction is characterized by dynamic impairment of active relaxation and contraction of the left ventricle on exercise and associated with myocardial energy deficiency. J Am Coll Cardiol 2009;54:402-409.

8. Borlaug BA, Lam CSP, Roger VL, et al. Contractility and ventricular systolic stiffening in hypertensive heart disease. Insight into the pathogenesis of heart failure with preserved ejection fraction. J Am Coll Cardiol 2009;54 410-418.

9. Tan YT, Wenzelburger $F$, Lee $E$, et al. The pathophysiology of heart failure with normal ejection fraction. Exercise echocardiography reveals complex abnormalities of both systolic and diastolic ventricular function involving torsion, untwist, and longitudinal motion. J Am Coll Cardiol 2009;54:36-46.

10. Meluzín J, Špinarová L, Hude P, et al. Left ventricular mechanics in idiopathic dilated cardiomyopathy: systolic-diastolic coupling and torsion. J Am Soc Echocardiogr 2009;22:486-493.

11. Paulus WJ, Tschope C, Sanderson JE, et al. How to diagnose diastolic heart failure: a consensus statement on the diagnosis of heart failure with normal left ventricular ejection fraction by the Heart Failure and Echocardiography Associations of the European Society of Cardiology. Eur Heart J 2007;28: 2539-2550.

12. Sundereswaran L, Nagueh SF, Vardan S, et al. Estimation of left and right ventricular filling pressures after heart transplantation by tissue Doppler imaging. Am J Cardiol 1998;82:352-357.

13. Agricola $E$, Galderisi $M$, Oppizzi M, et al. Doppler tissue imaging: a reliable method for estimation of left ventricular filling pressure in patients with mitral regurgitation. Am Heart J 2005;150:610-615.

14. Sharma R, Pellerin D, Gaze DC, et al. Mitral peak Doppler E-wave to peak mitral annulus velocity ratio is an accurate estimate of left ventricular filling pressure and predicts mortality in end-stage renal disease. J Am Soc Echocardiogr 2006;19:266-273.

15. Nagueh SF, Middleton KJ, Kopelen HA, et al. Doppler tissue imaging: a noninvasive technique for evaluation of left ventricular relaxation and estimation of filling pressures. J Am Coll Cardiol 1997;30:1527-1533.

16. Ommen SR, Nishimura RA, Appleton CP, et al. Clinical utility of Doppler echocardiography and tissue Doppler imaging in the estimation of left ventricular filling pressures. Circulation 2000;102:1788-1794.

17. Tartiére JM, Logeart D, Tartiére-Kesri L, Cohen-Solal A. Colour tissue Doppler underestimates myocardial velocity as compared to spectral tissue Doppler: poor reliability between both methods. Eur J Echocardiogr 2008;9: $268-272$.
18. Westermann $D$, Kasner $M$, Steendijk $P$, et al. Role of left ventricular stiffness in heart failure with normal ejection fraction. Circulation 2008;117: 2051-2060.

19. Burgess Ml, Jenkins C, Sharman JE, Marwick TH. Diastolic stress echocardiography: hemodynamic validation and clinical significance of estimation of left ventricular filling pressure with exercise. J Am Coll Cardiol 2006;47: $1891-1900$

20. Tighe DA, Vinch CS, Hill JC, et al. Influence of age on assessment of diastolic function by Doppler tissue imaging. Am J Card 2003;91:254-257.

21. Munagala VK, Jacobsen SJ, Mahoney DW, et al. Association of newer diastolic function parameters with age in healthy subjects: a population-based study. J Am Soc Echocardiogr 2003;16:1049-1056.

22. De Sutter J, De Backer J, Van de Veire N, et al. Effects of age, gender, and left ventricular mass on septal mitral annulus velocity $\left(E^{\prime}\right)$ and the ratio of transmitral early peak velocity to $E^{\prime}\left(E / E^{\prime}\right)$. Am J Cardiol 2005;95:1020-1023.

23. Remmen JJ, Aengevaeren WR, Verheugt FWA, Jansen RWMM. Normal values of pulmonary capillary wedge pressure and blood pressure to the Valsava manoeuvre in healthy elderly subjects. Clin Physiol Funct Imaging 2005;25:318-326.

24. Firstenberg MS, Levine BD, Garcia MJ, et al. Relationship of echocardiographic indices to pulmonary capillary wedge pressures in healthy volunteers. J Am Coll Cardiol 2000;36:1664-1669.

25. Prasad A, Okazaki K, Zadeh AA, et al. Abnormalities of Doppler measures of diastolic function in the healthy elderly are not related to alterations of left atrial pressure. Circulation 2005;111:1499-1503.

26. Ha JW, Lulic F, Bailey KR, et al. Effects of treadmill exercise on mitral inflow and annular velocities in healthy adults. Am J Cardiol 2003;91:114-115.

27. Ha JW, Choi EY, Choi D, et al. Time course of recovery of left ventricular filling pressure after exercise in healthy subjects. Circ J 2008;72:186-188.

28. Okada RD, Osbakken MD, Boucher CA, et al. Pulmonary blood volume ratio response to exercise: a noninvasive determination of exercise-induced changes in pulmonary capillary wedge pressure. Circulation 1982;65: $126-133$.

29. Higginbotham MB, Morris KG, Williams RS, et al. Regulation of stroke volume during submaximal and maximal upright exercise in normal man. Circ Res 1986;58:281-291.

30. Thadani U, Parker JO. Hemodynamics at rest and during supine and sitting bicycle exercise in normal subjects. Am J Cardiol 1978;41:52-59.

31. Rustad LA, Amundsen BH, Slordahl SA, Stoylen A. Upright bicycle exercise echocardiography in patients with myocardial infarction shows lack of diastolic, but not systolic, reserve: a tissue Doppler study. Eur J Echocardiogr 2009;10:503-508.

32. Podolec $P$, Rubis $P$, Tomkiewicz-Pajak $L$, et al. Usefulness of the evaluation of left ventricular diastolic function changes during stress echocardiography in predicting exercise capacity in patients with ischemic heart failure. J Am Soc Echocardiogr 2008:21:834-840.

33. Ha JW, Oh JK, Pellikka P, et al. Diastolic stress echocardiography: a novel noninvasive diagnostic test for diastolic dysfunction using supine bicycle exercise Doppler echocardiography. J Am Soc Echocardiogr 2005;18: 63-68.

34. Donal E, Raud-Raynier P, De Place Ch, et al. Resting echocardiographic assessment of left atrial function and filling pressure interest in the understanding of exercise capacity in patients with chronic congestive heart failure. J Am Soc Echocardiogr 2008;21:703-710.

35. Fukuta $H$, Little WC. Elevated left ventricular filling pressure after maximal exercise predicts increased plasma B-type natriuretic peptide levels in patients with impaired relaxation pattern of diastolic filling. J Am Soc Echocardiogr 2007;20:832-837.

36. Talreja DR, Nishimura RA, Oh JK. Estimation of left ventricular filling pressure with exercise by Doppler echocardiography in patients with normal systolic function: a simultaneous echocardiographic-cardiac catheterization study. J Am Soc Echocardiogr 2007;20:477-479.

37. Dalsgaard $M$, Kjaergaard J, Pecini $R$, et al. Left ventricular filling pressure estimation at rest and during exercise in patients with severe aortic valve stenosis: comparison of echocardiographic and invasive measurements. J Am Soc Echocardiogr 2009;22:343-349.

38. Dumesnil JG, Paulin Ch, Pibarot $P$, et al. Mitral annulus velocities by Doppler tissue imaging: practical implications with regard to preload alterations, sample position, and normal values. J Am Soc Echocardiogr 2002;15: 1226-1231.

39. Firstenberg MS, Greenberg NL, Main ML, et al. Determinants of diastolic myocardial tissue Doppler velocities: influences of relaxation and preload. J Appl Physiol 2001;90:299-307.

40. Nakajima Y, Kane GC, McCully RB, et al. Left ventricular diastolic filling pressures during dobutamine stress echocardiography: relationship to symptoms and ischemia. J Am Soc Echocardiogr 2009;22:947-953.

Received 29. 9. 2009 